\title{
The Antioxidant Effect of Green Tea, Rosemary, and Their Combination on Resin Bond Strength to Bleached Tooth Structures
}

\section{Ağartılmış Diş Dokularına Rezin Bağlanma Dayanımında Yeşil Çay, Biberiye ve Bunların Kombinasyonunun Antioksidan Etkileri}

\author{
(D) Süveybe Gündoğdu¹, (D) Nasibe Aycan Yılmaz² \\ ${ }^{1}$ Oral and Dental Health Center, Clinic of Restorative Dentistry, Erzurum, Turkey \\ ${ }^{2}$ Aydın Adnan Menderes University Faculty of Dentistry, Department of Restorative Dentistry, Aydın, Turkey
}

Keywords

Enamel, dentin, tooth bleaching, shear strength, antioxidants

\section{Anahtar Kelimeler}

Mine, dentin, dişağartma tedavisi, makaslama bağlanma dayanımı, antioksidanlar

Received/Geliş Tarihi : 05.08.2020

Accepted/Kabul Tarihi : 22.09.2020

doi:10.4274/meandros.galenos.2020.94914

Address for Correspondence/Yazışma Adresi: Nasibe Aycan Yılmaz MD,

Aydın Adnan Menderes University Faculty of Dentistry, Department of Restorative Dentistry, Aydın, Turkey

Phone : +90 5063584849

E-mail : dt.aycanyilmaz@yahoo.com

ORCID ID: orcid.org/000-0001-5939-8170

(c) Meandros Medical and Dental Journal, Published by Galenos Publishing House.

This is article distributed under the terms of the

Creative Commons Attribution NonCommercial 4.0

International Licence (CC BY-NC 4.0).

\begin{abstract}
Objective: This study aimed to evaluate the effect of four experimental antioxidant protocols on the shear bond strength of a resin-based composite to bleached the enamel and dentin.

Materials and Methods: Using extracted bovine incisors, 140 enamel/140 dentin specimens were prepared. Both enamel and dentin samples were assigned into seven groups, individually $(n=20)$ : $E N C / D N C=$ negative control, $E P C / D P C=$ positive control, EDR/DDR= delayed restoration, ESA/DSA= sodium ascorbate, EGT/DGT= green tea, $E R / D R=$ rosemary and $E G T R / D G T R=$ green tea and rosemary combination. Experimental antioxidant solutions prepared from sodium ascorbate, green tea, or rosemary extracts were applied to the bleached enamel/dentin samples in the ESA/DSA, EGT/DGT and ER/DR groups, respectively. The mixture of the green tea/ rosemary extract solutions at a 1:1 ratio was applied to the EGTR/DGTR groups to investigate possible synergistic antioxidant interaction. The shear bond strength (SBS) test was conducted at a crosshead speed of $0.5 \mathrm{~mm} /$ minute. Failure modes were assessed under a stereomicroscope at $\times 40$ magnification. Data were analysed statistically using Welch-ANOVA and Tamhane post-hoc tests.

Results: The lowest and highest mean SBS values were obtained in the positive control groups (EPC/DPC) and negative control groups (ENC/DNC), respectively $(p<0.05)$. Delaying of the composite resin restorations for 15 days improved bonding to the bleached enamel/dentin compared to the positive control groups $(p<0.05)$. All the antioxidant protocols, except green tea and rosemary combination, exhibited a bonding strength that was statistically similar to that of the relevant delayed restoration groups ( $p>0.05)$. Synergistic antioxidant interaction could not be obtained in the green tea and rosemary combination protocol.

Conclusion: Natural plant-derived antioxidants can be an alternative to synthetic sodium ascorbate and may enable immediate resin restorations of bleached tooth structures.
\end{abstract}

Öz

Amaç: Bu çalışmanın amacl, ağartıımış mine ve dentine kompozit rezin bağlanma dayanımında dört farklı antioksidan tedavi protokolünün etkisini değerlendirmektir. 
Gereç ve Yöntemler: Çalışmada 280 adet çekilmiş sığır keser dişinden 140'ar adet mine ve dentin örneği elde edildi. Mine ve dentin örnekleri kendi aralarında yedişer gruba ayrıldı $(\mathrm{n}=20): \mathrm{ENC} / \mathrm{DNC}=$ negatif kontrol, $E P C / D P C=$ pozitif kontrol, $E D R / D D R=$ ertelenmiş restorasyon, ESA/DSA= sodyum askorbat, EGT/DGT= yeşil çay, ER/DR= biberiye, EGTR/DGTR= yeşil çay ve biberiye kombinasyonu. Sodyum askorbat, yeşil çay ekstraktı, biberiye ekstraktı ve yeşil çay ve biberiye ekstrakt kombinasyonundan \%10 konsantrasyonda hazırlanan deneysel antioksidan solüsyonları ESA/DSA, EGT/DGT, ER/DR ve EGTR/DGTR gruplarında yer alan örneklerin ağartılmış mine/dentin yüzeylerine uygulandı. Makaslama bağlanma dayanımı (MBD) analizi, kafa hızı 0,5 mm/dakika olarak ayarlanan test cihazında gerçekleştirildi. Kırılma tipleri, stereomikroskop altında x40 büyütme ile değerlendirildi. Verilerin istatistiksel analizinde Welch ANOVA ve post-hoc Tamhane testleri kullanıldı.

Bulgular: En düşük ve en yüksek MBD değerleri pozitif kontrol (EPC/DPC) ve negatif kontrol (ENC/DNC) gruplarında bulundu $(p<0,05)$. Kompozit rezin restorasyonların 15 gün süreyle ertelenmesi (EDR/DDR) ağartılmış mine/dentine bağlanmayı pozitif kontrol gruplarına kıyasla arttırdı $(p<0,05)$. Yeşil çay ve Biberiye kombinasyonu hariç tüm antioksidan protokollerinde, ertelenmiş restorasyon gruplarına benzer düzeyde bağlanma dayanımı elde edildi $(p>0,05)$. Yeşil çay ve biberiye kombinasyon protokolünde sinerjistik antioksidan etki elde edilemedi.

Sonuç: Bitkisel kaynaklı doğal antioksidanlar, sentetik sodyum askorbata alternatif olabilir ve ağartılmış diş dokularının rezin içerikli materyallerle hemen restore edilebilmesini sağlayabilirler.

\section{Introduction}

Tooth bleaching is a conservative, rapid, and lowcost option for the esthetic treatment of discolored teeth. In case when the bleaching treatment could not fulfill the esthetic expectations of the individuals, additional restorative treatment may be needed, or existing restorations may have to be renewed (1). Nevertheless, extensive research has shown that the bond strength between freshly bleached tooth structures and the resin-based restorative materials is compromised (2-8). This problem was primarily due to the decomposition by-products of HP, which are residual oxygen and free radicals released in the form of hydroxyl, per-hydroxyl, and superoxide anions $(9,10)$. For these by-products to be removed from the oxidized tooth structures, a waiting period of 1-3 weeks was recommended in the literature (1). From a clinical perspective, delaying the restorations for a certain time and increasing the number of sessions may not be well-tolerated by the individuals expecting for their treatment to be concluded in a shorter time $(11,12)$.

Immediate application of the antioxidants to freshly bleached tooth surfaces has been recommended to benefit from their free radical scavenging activities (1). Antioxidants are compounds that can neutralize free radicals by donating their electrons. Upon application of the antioxidants, residual oxygen and the free radicals trapped within oxidized tooth structures are removed and consequently, the compromised bonding of the resin-based restorative materials to tooth structures is improved. Immediate post-bleaching application of the antioxidants can facilitate the resin-based adhesive restorative procedures to be completed in the same session and reduce the need for another dental visit $(1,13)$.

Among various antioxidants, $10 \%$ sodium ascorbate has been the most widely investigated antioxidant in laboratory studies (13). Sodium ascorbate is the sodium salt of ascorbic acid, also known as vitamin C. Although its free radical scavenging/ antioxidant activity on oxidized enamel/dentin has been demonstrated in numerous in vitro studies (1$3,12-14)$, sodium ascorbate application remains an experimental approach that has no place in the clinical setting. The disadvantage of using sodium ascorbate is that it is highly sensitive to ambient conditions such as heat, light, oxygen, humidity, $\mathrm{pH}$ and that it loses its stability and effectiveness rapidly (15).

Recently, researchers have focused on natural plant extracts to develop a non-toxic, biocompatible, and effective antioxidant protocol which can be applied safely to oxidized dental structures. Flavonoids, phenolic compounds or their derivatives in the composition of the natural plant extracts can prevent auto-oxidation via different mechanisms such as reducing or inhibiting oxygen formation, free radical scavenging, or metal ion chelating (16). Several natural antioxidant sources $(1,4-6,17)$ have been investigated, yet there lacks a plant-derived natural antioxidant protocol developed for use in daily clinical practice.

As the natural plant-derived antioxidants, freshly prepared green tea (Camellia sinensis) and rosemary 
(Rosmarinus officinalis L.) extracts were investigated in this study, in terms of their free radical scavenging effects on bleached enamel/dentin.

Despite their well-documented antioxidant effects in literature, research related to the free radical scavenging effects of the green tea and rosemary extracts on the oxidized tooth structures is quite limited $(4,5,17)$.

Research in the pharmaceutical and food industry have demonstrated that synergistic interaction resulting from the combination of antioxidant plant extracts or isolated pure compounds can be beneficial. The mixture of phytochemical and/or synthetic bioactive compounds may exert greater bioactivity than a single compound and become more effective in the oxidation process $(16,18-20)$. Previously, no study has investigated the possible synergistic antioxidant interaction on the oxidized tooth structures. In this study, to investigate any possible synergistic interaction on bleached enamel/ dentin, experimental antioxidant solutions prepared from green tea and rosemary extracts were combined in a 1:1 ratio. To the best of our knowledge, this is the first study that investigates synergistic antioxidant interaction that could be advantageous in neutralizing free radicals within oxidized tooth structures.

This study aimed to comparatively evaluate three different natural antioxidant protocols prepared from green tea extract, rosemary extract, and their 1:1 combination as well as a synthetic antioxidant protocol prepared from sodium ascorbate (SA) in terms of their effects on improving compromised bond strength to bleached enamel/dentin. Those hypotheses were tested in this study:

1. All experimental antioxidant protocols applied after bleaching will improve enamel-resin or dentinresin shear bond strength, compared to positive control.

2. There will be no difference between the antioxidant protocols in terms of improving bond strength to bleached enamel/dentin.

\section{Materials and Methods}

\section{Preparation of the Enamel and Dentin Samples}

G-Power v.3.1.9.2 software (Heinrich Heine, University of Düsseldorf, Düsseldorf, Germany) was used to determine the required minimum sample size according to the data of a previous research (21). Based on the parameters of an alpha-type error of 0.05 , a beta power of 0.95 , and an effect size of 0.40 , the minimal estimated sample size per group was found to be 20. Considering the 7 individual groups for both enamel and dentin samples, 280 teeth in total (140 enamel samples and 140 dentin samples) were included in the study.

Two-hundred-eighty bovine incisors obtained from a slaughterhouse were used in the study. Extracted teeth were cleaned from soft tissue remnants with a periodontal curette under running water and then

\begin{tabular}{|c|c|c|c|}
\hline $\begin{array}{l}\text { Enamel groups } \\
(n=20)\end{array}$ & Bleaching & Antioxidant protocol & $\begin{array}{l}\text { Restoration } \\
\text { delay time }\end{array}$ \\
\hline Enamel-negative control & - & - & - \\
\hline Enamel-positive control & $\begin{array}{l}40 \% \mathrm{HP} \\
20 \mathrm{~min} \times 3\end{array}$ & - & - \\
\hline Enamel-delayed restoration & $\begin{array}{l}40 \% \mathrm{HP} \\
20 \mathrm{~min} \times 3\end{array}$ & - & 15 days \\
\hline Enamel-sodium ascorbate & $\begin{array}{l}40 \% \mathrm{HP} \\
20 \mathrm{~min} \times 3\end{array}$ & $10 \%$ Sodium ascorbate, $10 \mathrm{~min}$ & - \\
\hline Enamel-green tea & $\begin{array}{l}40 \% \mathrm{HP} \\
20 \mathrm{~min} \times 3\end{array}$ & $10 \%$ Green tea, $10 \mathrm{~min}$ & - \\
\hline Enamel-rosemary & $\begin{array}{l}40 \% \mathrm{HP} \\
20 \mathrm{~min} \times 3\end{array}$ & $10 \%$ Rosemary, $10 \mathrm{~min}$ & - \\
\hline Enamel-green tea and rosemary & $\begin{array}{l}40 \% \mathrm{HP} \\
20 \mathrm{~min} \times 3\end{array}$ & $10 \%$ Green tea \& rosemary, $10 \mathrm{~min}$ & - \\
\hline
\end{tabular}


disinfected by immersing in the $0.1 \%$ thymol solution for 1 week. The teeth were kept in distilled water until the experiment and used within one month.

Each tooth was separated from its cementoenamel junction by using a diamond separator equipped with a handpiece and a micromotor working at the slow speed. The roots were removed away, and the crowns were divided into two segments as facial and lingual, by cutting at the inciso-apical direction. The facial tooth segments were embedded in auto-polymerizing acrylic resin placed in polyvinyl chloride molds with enamel surfaces facing upward.

Of all the tooth segments, 140 were used directly as enamel samples. The remaining 140 teeth were converted to dentin samples by removing their enamel layer with a \#010 diamond bur equipped with an aerator under water cooling. The enamel/dentin surface of each sample was wet-grinded with a 600grit silicon carbide paper for $15 \mathrm{~s}$ to obtain a standard smear layer and a flat surface. Enamel and dentin samples were divided individually into 7 groups, according to the treatment protocols (Tables 1, 2). Each group consisted of 20 enamel/dentin samples $(n=20)$ :

ENC/DNC: Enamel/dentin negative control groups. No bleaching or antioxidant was applied.

EPC/DPC: Enamel/dentin positive control groups. Restorations were performed immediately after bleaching treatment. No antioxidant was applied.
EDR/DDR: Enamel/dentin delayed restoration groups. After bleaching, all samples were kept in distilled water in an incubator, at $37{ }^{\circ} \mathrm{C}$ for 2 weeks. No antioxidant was applied.

ESA/DSA: Enamel/dentin sodium ascorbate groups. After bleaching, all samples were immediately treated with the sodium ascorbate antioxidant solution.

EGT/DGT: Enamel/dentin green tea groups. After bleaching, all samples were immediately treated with the green tea antioxidant solution.

ER/DR: Enamel/dentin rosemary groups. After bleaching, all samples were immediately treated with the rosemary antioxidant solution.

EGTR/DGTR: Enamel/dentin green tea and rosemary combination groups. After bleaching, all samples were immediately treated with the green tea and rosemary combination solution.

Bleaching Treatment of the Enamel and Dentin Samples

Except for the samples in negative control groups, ENC and DNC, all samples were treated with in-office bleaching (Opalescence Boost PF, Ultradent, Inc., South Jordan UT, USA) according to the manufacturer's instructions. Forty percent HP containing bleaching gel was applied on the enamel/dentin surfaces at 1-mm-thickness. The bleaching gel was left in place undisturbed for 20 minutes on the enamel samples or 10 minutes on the dentin samples. Afterward, the

\begin{tabular}{|c|c|c|c|}
\hline $\begin{array}{l}\text { Dentin groups } \\
(n=20)\end{array}$ & Bleaching & Antioxidant protocol & $\begin{array}{l}\text { Restoration } \\
\text { delay time }\end{array}$ \\
\hline Dentin-negative control & - & - & - \\
\hline Dentin-positive control & $\begin{array}{l}40 \% \mathrm{HP} \\
10 \min \times 3\end{array}$ & - & - \\
\hline Dentin-delayed restoration & $\begin{array}{l}40 \% \mathrm{HP} \\
10 \mathrm{~min} \times 3\end{array}$ & - & 15 days \\
\hline Dentin-sodium ascorbate & $\begin{array}{l}40 \% \mathrm{HP} \\
10 \min \times 3\end{array}$ & $10 \%$ Sodium ascorbate, $10 \mathrm{~min}$ & - \\
\hline Dentin-green tea & $\begin{array}{l}40 \% \mathrm{HP} \\
10 \min \times 3\end{array}$ & $10 \%$ Green tea, $10 \mathrm{~min}$ & - \\
\hline Dentin-rosemary & $\begin{array}{l}40 \% \mathrm{HP} \\
10 \mathrm{~min} \times 3\end{array}$ & $10 \%$ Rosemary, $10 \mathrm{~min}$ & - \\
\hline Dentin-green tea and rosemary & $\begin{array}{l}40 \% \mathrm{HP} \\
10 \mathrm{~min} \times 3\end{array}$ & $10 \%$ Green tea and rosemary, $10 \mathrm{~min}$ & - \\
\hline
\end{tabular}


bleaching gel was removed gently with a gauze patch and the bleached surfaces were rinsed with distilled water for $60 \mathrm{~s}$. The bleaching procedure was repeated in 3 consecutive applications. Bleached enamel and dentin samples in delayed restoration groups (EDR/ DDR) were kept in the incubator at $37{ }^{\circ} \mathrm{C}$ within distilled water for 15 days.

\section{Preparation of the Green Tea and Rosemary Extracts}

Pure plant extracts (Camellia sinensis and Rosmarinus officinalis $\mathrm{L}$.) were used in the preparation of experimental antioxidant solutions in this study. Taxonomical identification of the plants was performed in the Department of Biology, Faculty of Arts and Sciences, Aydın Adnan Menderes University.

Twenty-five grams of dried green tea sample and $200 \mathrm{~mL}$ of ethanol were placed into a beaker. The beaker was sealed with the parafilm and shaken on a bench-top shaker (Promax 2020, Heidolph, Kelheim, Germany) at $120 \mathrm{rpm}$ for $2 \mathrm{~h}$. Afterward, all ingredient within the beaker was transferred into a blender and mixed. The resulting mixture was filtered through a black ribbon filter paper and the (first) filtrate was kept in the dark at $+4{ }^{\circ} \mathrm{C}$. Subsequently, the green tea residue was treated with $200 \mathrm{~mL}$ of ethanol and shaken under the same conditions for $24 \mathrm{~h}$. The (second) filtrate and the residue were separated by filtration. Repeatedly, $100 \mathrm{~mL}$ of ethanol was added on the plant residue, shaken for another $2 \mathrm{~h}$ and filtrated as described above. The residue was discarded, and the filtrates obtained at the end of three successive filtration processes were combined. Thus, the phenolic compounds within the composition of green tea were extracted into ethanol. The ethanol was removed from the filtrate in a rotary evaporator (RE, IKA RV 05 basic $1 B$, Staufen, Germany) at $+40^{\circ} \mathrm{C}$. The extract solution was transferred from the evaporator flask to the petri dish, by dissolving in approximately $10.0 \mathrm{~mL}$ of ethanol, and then dried in the incubator at $+40{ }^{\circ} \mathrm{C}$ for $12 \mathrm{~h}$, to remove all solvent. Freshly prepared green tea extracts were kept at $-18{ }^{\circ} \mathrm{C}$, until use.

Thirty-nine grams of the rosemary sample and 300 $\mathrm{mL}$ of ethanol were placed into a beaker. The beaker was sealed with the parafilm, and then subsequent procedures were repeated as described for the preparation of green tea extract.

\section{Preparation and the Application of the Experimental Antioxidant Solutions}

The amounts of the plant extracts and sodium ascorbate powder were weighed on an analytical balance (Radwag, AS 220/C/2, Radom, Poland). Distilled water was measured using an automatic pipette (Isolab Pipette by CAPP, Wertheim, Germany).

Experimental $10 \%$ sodium ascorbate solution was prepared by dissolving $10 \mathrm{~g}$ of sodium ascorbate powder (Sigma-Aldrich, St. Louis, USA) in $100 \mathrm{~mL}$ distilled water. Its $\mathrm{pH}$ value was measured with a $\mathrm{pH}$ meter (Hanna, pH211, Rhode Island, USA) ( $\mathrm{pH}=7.76)$.

Ten grams of green tea extract and $100 \mathrm{~mL}$ distilled water were combined in a glass beaker. The beaker was sealed with the parafilm and the mixture was stirred on a heated magnetic stirrer (Promax 2020, GmbH \& Co KG, Kelheim, Germany) at $70{ }^{\circ} \mathrm{C}$ for $15 \mathrm{~min}$. Then the glass beaker was taken into the ultrasonic bath (Apple, Ultrasonic LC 30, Germany) and incubated for 15 min under ultrasonic vibration. Following this step, the mixture was transferred to microcentrifuge tubes and blended for another $15 \mathrm{~min}$ in a centrifuge (Sigma 3-30 K, Germany). At the end of the spinning period, the mixture was passed through filter paper twice to remove the precipitate and the filtrated liquid was used as the $10 \%$ green tea antioxidant solution in the study ( $\mathrm{pH}=5.69)$.

To prepare the $10 \%$ rosemary antioxidant solution, $10 \mathrm{gr}$ rosemary extract and $100 \mathrm{~mL}$ of distilled water were taken into a glass beaker. All other procedures were performed as described above for the preparation of green tea antioxidant solution. $(\mathrm{pH}=5.23)$.

Ten percent green tea and $10 \%$ rosemary solutions were mixed in a ratio of $1: 1$ and $10 \%$ green tea \& rosemary combination solution was prepared $(\mathrm{pH}=5.33)$.

All experimental antioxidant solutions were kept in tightly closed glass jars in the refrigerator at $+4{ }^{\circ} \mathrm{C}$ until the experiment and used within a week. Antioxidant solutions were applied to the bleached enamel/ dentin surfaces of the samples in the experimental antioxidant groups ESA/DSA, EGT/DGT, ER/DR, and EGTR/DGTR. Application of the antioxidant solutions was performed actively by rubbing on the enamel/ dentin surfaces with a microbrush for $10 \mathrm{~min}$, and the solutions were refreshed each $\min$. Then the samples were rinsed with distilled water for $20 \mathrm{~s}$. 


\section{Composite Resin Restoration}

The enamel and dentin surfaces of the samples were conditioned with $35 \%$ phosphoric acid gel (K-Etchant, Kuraray, New York, USA) for $30 \mathrm{~s}$ or 15 $\mathrm{S}$, respectively, and then rinsed with distilled water thoroughly. Enamel samples were dried using an air-water syringe. A gentle airstream was applied to dentin samples for 4-5 s, to keep dentin surfaces humid. Two-step etch \& rinse adhesive system (Adper Single Bond 2, 3M ESPE, St. Paul, MN, USA) was applied in two consecutive layers on sample surfaces according to the manufacturer's instructions. Each adhesive layer was rubbed onto the sample surface with a microbrush for about $15 \mathrm{~s}$. Next, the adhesive applied surfaces were gently air-streamed for $5 \mathrm{~s}$ to remove the solvent and then polymerized for $10 \mathrm{~s}$ with an LED light-curing unit (Monitex, New Taipei City, Taiwan).

Transparent plastic tubes (4-mm-height $\times 4-m m-$ width) employed as the templates were positioned at the center of each sample surface. A 2-mm-thick micro-hybrid composite resin layer (Filtek Z250, 3M ESPE, St. Paul, MN, USA) was inserted within each template and then light-cured for $20 \mathrm{~s}$. The second composite resin layer was applied and light-cured for $20 \mathrm{~s}$. The templates were removed with a scalpel, and composite resin restorations were light-cured for an additional $20 \mathrm{~s}$. Following the completion of the buildup restorations, all samples were transferred into distilled water and kept in an incubator (Hera Therm, Thermo Fisher Scientific Co., USA) at $37{ }^{\circ} \mathrm{C}$ for $24 \mathrm{~h}$. The contents of the materials used in the study are given in Table 3.

\section{Shear Bond Strength Test}

Shear bond strength was measured with a shear test device equipped with a software (Mode Dental, Esetron Smart Robotechnologies, Ankara, Turkey). First, the data regarding the restoration surface area $\left(12.56 \mathrm{~mm}^{2}\right)$, the maximum load $(500 \mathrm{~N})$, and the crosshead speed $(0.5 \mathrm{~mm} / \mathrm{min})$ were entered into the software and then, each sample was connected to the test device. SBS values at the moment of fracture were recorded automatically as $\mathrm{N}$ and $\mathrm{MPa}\left(\mathrm{N} / \mathrm{mm}^{2}\right)$ (Tables 4, 5).

The fracture interfaces of the samples were examined at $\times 40$ magnification under a stereomicroscope (Olympus SZ61, Munster, Germany) equipped with an imaging system (Olympus cellSens Standard, Munster, Germany). The fracture types were recorded as adhesive, cohesive, or mixed. The adhesive fracture represented the failure that occurred at enamel/adhesive or dentin/adhesive interface. The cohesive fracture represented the failure that occurred within the composite resin, dentin, or enamel. The mixed fracture was defined when the failure occurred both in adhesive and cohesive types. The numbers and the percentages of the fracture types are given in Table 4 and Table 5.

\section{Statistical Analysis}

SPSS 25 software (IBM SPSS Statistics, Armonk, NY, USA) was used for the statistical analysis. The SBS data of the enamel and dentin groups were compared within themselves, yet not between each other. Lilliefors corrected Kolmogorov-Smirnov test, orthogonality-skewness coefficients, and histogram were used to determine the suitability of the data

\begin{tabular}{|c|c|c|c|}
\hline Brand & Material & Composition & Manufacturer \\
\hline $\begin{array}{l}\text { Filtek Z250 } \\
\text { LOT: N842589 }\end{array}$ & $\begin{array}{l}\text { Microhybrid composite } \\
\text { resin }\end{array}$ & $\begin{array}{l}\text { Inorganic fillers (\%60), Bis-GMA, UDMA, } \\
\text { Bis-EMA }\end{array}$ & 3M ESPE, St. Paul, MN, USA \\
\hline $\begin{array}{l}\text { K-Etchant } \\
\text { LOT: } 2 Q 0035\end{array}$ & Acid gel & $35 \%$ phosphoric acid & Kuraray Co., Osaka, JAPAN \\
\hline $\begin{array}{l}\text { Adper Single Bond } 2 \\
\text { LOT: N853720 }\end{array}$ & $\begin{array}{l}\text { Two-step etch\&rinse } \\
\text { adhesive resin }\end{array}$ & $\begin{array}{l}\text { Bis-GMA, HEMA, dimethacrylates, } \\
\text { ethanol, water, photoinitiator system, } \\
\text { methacrylate functional copolymer of } \\
\text { polyacrylic and polyitaconic acids, silica } \\
\text { nanofiller }\end{array}$ & 3M ESPE, St. Paul, MN, USA \\
\hline $\begin{array}{l}\text { Opalescence Boost PF } \\
\text { LOT: M1080108 }\end{array}$ & In-Office bleaching gel & $\begin{array}{l}40 \% \text { hydrogen peroxide gel, fluoride, } \\
\text { potassium nitrate }\end{array}$ & $\begin{array}{l}\text { Ultradent, South Jordan UT, } \\
\text { USA }\end{array}$ \\
\hline $\begin{array}{l}\text { Sodium L-ascorbate } \\
\text { LOT: BCBT } 8088\end{array}$ & Synthetic antioxidant & $\begin{array}{l}\mathrm{L}(+) \text {-Ascorbic acid sodium salt } \mathrm{C} 6 \mathrm{H} 7 \mathrm{NaO} 6 \\
\text { BioXtra, }{ }^{3} \% 99\end{array}$ & $\begin{array}{l}\text { Sigma- Aldrich, St. Louis, } \\
\text { USA }\end{array}$ \\
\hline
\end{tabular}


to normal distribution. Levene's test was used to analyze the homogeneity of variances. Since the data were distributed normally, yet the variances were not homogeneous, the Welch ANOVA test was performed. Tamhane post-hoc test was used to evaluate the differences between the groups. Significance was evaluated at the level of $p<0.05$.

\section{Results}

The mean, standard deviation ( \pm SD) SBS value (in $\mathrm{MPa}$ ) and fracture types of the enamel and dentin groups are shown in Table 4 and Table 5.

The lowest and highest mean SBS values were obtained in positive control groups (EPC/DPC) $(p<0.05)$ and negative control groups (ENC/DNC) $(p<0.05)$, respectively. The lowest and highest rate of adhesive type fractures were observed in negative control groups (ENC/DNC) and positive control groups (EPC/DPC), respectively.

The mean SBS value measured in the delayed restoration groups (EDR/DDR) were significantly higher $(p<0.05)$, and the rate of the adhesive type failures were lower compared to the positive control groups. The mean SBS data measured in the enamel delayed restoration group (EDR) did not reach the level of enamel negative control group (ENC) $(p<0.05)$. The mean SBS data measured in the dentin delayed restoration (DDR) reached to a level that was statistically similar to the dentin negative control group (DNC) ( $p>0.05)$.

All antioxidant-applied enamel and dentin groups exhibited relatively higher SBS values compared to EPC or DPC, respectively $(p<0.05)$. None of the antioxidant-applied enamel groups reached the SBS value that was statistically similar to ENC $(p<0.05)$. Of all antioxidant-applied dentin groups, only the sodium ascorbate group presented the SBS value that was statistically similar to DNC ( $p>0.05)$.

All antioxidant-applied enamel and dentin groups, except green tea and rosemary combination, exhibited the SBS value that was statistically similar to EDR or DDR, respectively $(p>0.05)$.

\section{Discussion}

In the present study, both the enamel and dentin samples in the positive control groups (EPC/DPC) exhibited lower bond strength data and a higher rate of adhesive type fracture compared to other groups. These findings were consistent with other studies (28) revealing the deterioration in resin bonding efficacy to freshly bleached dentin.

\begin{tabular}{|c|c|c|c|c|}
\hline \multirow{2}{*}{$\begin{array}{l}\text { Enamel } \\
\text { groups } \\
(n=20)\end{array}$} & \multirow{2}{*}{\begin{tabular}{|l} 
SBS value (MPa) \\
Mean ( \pm SD)*
\end{tabular}} & \multicolumn{3}{|c|}{ Fracture types } \\
\hline & & $\begin{array}{l}\text { Adhesive } \\
\mathrm{n},(\%)\end{array}$ & $\begin{array}{l}\text { Cohesive } \\
\text { n, (\%) }\end{array}$ & $\begin{array}{l}\text { Mix } \\
\text { n, (\%) }\end{array}$ \\
\hline ENC & $21.63( \pm 1.71)^{a}$ & \begin{tabular}{|l|}
10 \\
$(50 \%)$ \\
\end{tabular} & \begin{tabular}{|l}
4 \\
$(20 \%)$
\end{tabular} & \begin{tabular}{|l}
6 \\
$(30 \%)$ \\
\end{tabular} \\
\hline EPC & $7.14( \pm 1.35)^{\mathrm{b}}$ & \begin{tabular}{|l|}
15 \\
$(75 \%)$
\end{tabular} & \begin{tabular}{|l}
0 \\
$(0 \%)$
\end{tabular} & \begin{tabular}{|l|}
5 \\
$(25 \%)$
\end{tabular} \\
\hline EDR & $18.47( \pm 2.02)^{c}$ & \begin{tabular}{|l|}
12 \\
$(60 \%)$ \\
\end{tabular} & $\begin{array}{l}2 \\
(10 \%) \\
\end{array}$ & \begin{tabular}{|l}
6 \\
$(30 \%)$ \\
\end{tabular} \\
\hline ESA & $18.40( \pm 2.59)^{c}$ & \begin{tabular}{|l|}
12 \\
$(60 \%)$ \\
\end{tabular} & \begin{tabular}{|l}
2 \\
$(10 \%)$ \\
\end{tabular} & \begin{tabular}{|l}
6 \\
$(30 \%)$ \\
\end{tabular} \\
\hline EGT & $16.23( \pm 2.74)^{\mathrm{cd}}$ & \begin{tabular}{|l|}
14 \\
$(70 \%)$ \\
\end{tabular} & \begin{tabular}{|l}
1 \\
$(5 \%)$ \\
\end{tabular} & \begin{tabular}{|l}
5 \\
$(25 \%)$ \\
\end{tabular} \\
\hline ER & $15.96( \pm 3.01)^{\mathrm{cd}}$ & \begin{tabular}{|l|}
14 \\
$(70 \%)$ \\
\end{tabular} & \begin{tabular}{|l|}
1 \\
$(5 \%)$ \\
\end{tabular} & \begin{tabular}{|l}
5 \\
$(25 \%)$ \\
\end{tabular} \\
\hline EGTR & $14.92( \pm 2.44)^{d}$ & \begin{tabular}{|l|}
14 \\
$(70 \%)$
\end{tabular} & \begin{tabular}{|l}
0 \\
$(0 \%)$
\end{tabular} & \begin{tabular}{|l|}
6 \\
$(30 \%)$ \\
\end{tabular} \\
\hline \multicolumn{5}{|c|}{$\begin{array}{l}\text { *Significant differences between means are characterized by different lowercase letters ( } p<0.05) \text {. } \\
\text { ENC: Enamel negative control groups, EPC: Enamel positive control groups, EDR: Enamel delayed restoration groups, ESA: Enamel sodium ascorbate } \\
\text { groups, EGT:Enamel green tea groups, ER: Enamel rosemary groups, EGTR: Enamel green tea \& rosemary combination groups, SD: Standard deviation, } \\
\text { n: Number }\end{array}$} \\
\hline
\end{tabular}


Post-bleaching delay of restorations for 15 days could improve bonding to dentin (DDR) to the level that is statistically similar to the dentin-negative control group (DNC). However, in the enamel-delayed restoration group (EDR) bonding to enamel could not reach the level of the enamel-negative control group (ENC). Similar to our findings, in an in situ study Bittencourt et al. (7) detected that post-bleaching delay of the restorations for 7 or 14 days could not improve resin-enamel bond strength to the level of the enamel-control group, contrary to that observed in 21 days of restoration delay group. However, postbleaching delay of the restorations for 7,14 , or 21 days could improve bonding to dentin to the level of the dentin-control group.

All antioxidant groups (ESA/DSA, EGT/DGT, ER/ $D R, E G T R / D G T R$ ) exhibited higher mean SBS value and lower adhesive type failures compared to their relevant positive control groups (EPC/DPC), in which restorations were applied immediately after bleaching. Therefore, our first hypothesis stating that all experimental antioxidant protocols applied after bleaching would improve enamel-resin or dentinresin shear bond strength, compared to the positive control was accepted.
Among the experimental antioxidant protocols applied to the bleached dentin (DSA, DGT, DR, DGTR), no significant difference was observed in terms of improving SBS. However, of all antioxidant protocols applied to the bleached enamel, the green tea and rosemary combination protocol (EGTR) was found to be less effective in improving SBS, comparing to the sodium ascorbate protocol (ESA). Additionally, contrary to other antioxidant protocols, green tea and rosemary combination protocol failed to enhance bonding to enamel/dentin in EGTR/DGTR groups to the level of relative delayed restoration groups (EDR/ DDR). Therefore, our second hypothesis stating that there would be no difference between the antioxidant protocols in terms of improving bond strength to bleached enamel/dentin was partially rejected.

Free radical scavenging/antioxidant efficacy of sodium ascorbate on tooth structures has been welldocumented (13). However, controversial results also exist $(22,23)$, probably due to the variations in the experimental design of the studies. Various factors associated with the antioxidant protocol, e.g. the type/concentration of the antioxidant, the method/ duration of the application, etc. can make an impact on the penetration capacity of the bioactive antioxidant

\begin{tabular}{|c|c|c|c|c|}
\hline \multirow{2}{*}{$\begin{array}{l}\text { Dentin } \\
\text { groups } \\
(\mathrm{n}=\mathbf{2 0})\end{array}$} & \multirow{2}{*}{\begin{tabular}{|l|} 
SBS data $(\mathrm{MPa})$ \\
Mean $( \pm \mathrm{SD})^{*}$
\end{tabular}} & \multicolumn{2}{|c|}{ Fracture types } & \multirow[b]{2}{*}{$\begin{array}{l}\text { Mix } \\
\mathrm{n},(\%)\end{array}$} \\
\hline & & $\begin{array}{l}\text { Adhesive } \\
n,(\%)\end{array}$ & $\begin{array}{l}\text { Cohesive } \\
n,(\%)\end{array}$ & \\
\hline DNC & $12.75( \pm 1.78)^{\mathrm{A}}$ & \begin{tabular}{|l|}
13 \\
$(65 \%)$
\end{tabular} & \begin{tabular}{|l}
2 \\
$(10 \%)$
\end{tabular} & \begin{tabular}{|l}
5 \\
$(25 \%)$
\end{tabular} \\
\hline DPC & $3.73( \pm 1.71)^{\mathrm{B}}$ & \begin{tabular}{|l}
20 \\
$(100 \%)$ \\
\end{tabular} & \begin{tabular}{|l}
0 \\
$(0 \%)$ \\
\end{tabular} & \begin{tabular}{|l}
0 \\
$(0 \%)$ \\
\end{tabular} \\
\hline DDR & $11.24( \pm 1.94)^{\mathrm{AC}}$ & \begin{tabular}{|l|}
15 \\
$(75 \%)$
\end{tabular} & \begin{tabular}{|l|}
0 \\
$(0 \%)$
\end{tabular} & \begin{tabular}{|l|}
5 \\
$(25 \%)$
\end{tabular} \\
\hline DSA & $10.52( \pm 2.95)^{\mathrm{ACD}}$ & \begin{tabular}{|l|}
16 \\
$(80 \%)$ \\
\end{tabular} & \begin{tabular}{|l|}
0 \\
$(0 \%)$ \\
\end{tabular} & \begin{tabular}{|l}
4 \\
$(20 \%)$
\end{tabular} \\
\hline DGT & $10.17( \pm 2.56)^{\mathrm{CD}}$ & \begin{tabular}{|l|}
17 \\
$(85 \%)$ \\
\end{tabular} & \begin{tabular}{|l|}
0 \\
$(0 \%)$ \\
\end{tabular} & \begin{tabular}{|l}
3 \\
$(15 \%)$ \\
\end{tabular} \\
\hline DR & $9.38( \pm 2.89)^{\mathrm{CD}}$ & \begin{tabular}{|l|}
17 \\
$(85 \%)$ \\
\end{tabular} & \begin{tabular}{|l|}
0 \\
$(0 \%)$ \\
\end{tabular} & \begin{tabular}{|l}
3 \\
$(15 \%)$ \\
\end{tabular} \\
\hline DGTR & $8.57( \pm 2.68)^{\mathrm{D}}$ & \begin{tabular}{|l|}
18 \\
$(90 \%)$
\end{tabular} & \begin{tabular}{|l}
0 \\
$(0 \%)$
\end{tabular} & $\begin{array}{l}2 \\
(10 \%)\end{array}$ \\
\hline \multicolumn{5}{|c|}{$\begin{array}{l}\text { *Significant differences between means are characterized by different uppercase letters ( } p<0.05) \text {. } \\
\text { DNC: Dentin negative control groups, DPC: Dentin positive control groups, DDR: Dentin delayed restoration groups, DSA: Dentin sodium ascorbate } \\
\text { groups, DGT: Dentin green tea groups, DR: Dentin rosemary groups, DGTR: Dentin green tea \& rosemary combination groups, SD: Standard deviation } \\
\text { n: Number }\end{array}$} \\
\hline
\end{tabular}


constituent(s) through oxidized enamel/dentin. This finally determines the free-radical scavenging effect obtained on the tooth structures.

The duration of the SA application in studies vary between $1 \mathrm{~min}$ to $40 \mathrm{~h}$ (13). Lai et al. (2) suggested that the duration of the antioxidant application should be at least one-third of the duration of the bleaching treatment. Türkün and Kaya (3) showed that a 10 min treatment duration was sufficient to increase post-bleaching enamel-resin bond strength, provided that the SA solution was applied actively to the bleached tooth surfaces. Park et al. (12) reported that when applied passively, the penetration of SA to tooth structures would occur quite slowly and take time due to the simple diffusion mechanism. Several other researchers also stated that by applying actively and refreshing continuously, the antioxidant effect of SA on bleached tooth surfaces could be enhanced $(24,25)$. In another study, Freire et al. (14) revealed that the reaction of sodium ascorbate with the tooth surface reached its peak within $1 \mathrm{~min}$ and then gradually decreased. Researchers emphasized that the frequency of the SA application was more critical than the total application duration. In light of these findings, we applied SA to the bleached enamel/ dentin surfaces actively and kept refreshing the solution once in per min throughout the application for $10 \mathrm{~min}$.

The free radical scavenging effect of green tea extract on bleached enamel has been shown previously $(4,6,17)$, which is in line with our results. Green tea is a rich source of catechins [epigallocatechin gallate (EGCG), epigallocatechin (EGC), epicatechin gallate (ECG), epicatechin (EC)], and flavonols. The strong antioxidant activity of green tea has been associated with its high content of catechin and flavonol, which can neutralize free radicals by donating hydrogen from hydroxyl groups in their structure $(26,27)$.

Despite its well-documented antioxidant activity in the literature $(28,29)$, interestingly, only a single in vitro study has investigated the free radical scavenging potency of rosemary on the oxidized tooth structure. In this study, Suneetha et al. (5) comparatively evaluated the rosemary-derived natural antioxidant solution (at an unspecified concentration) with the 10\% sodium ascorbate solution on the enamel bleached with $10 \%$ carbamide peroxide. The researchers reported that both the rosemary-derived natural antioxidant protocol and SA showed satisfactory results in improving compromised resin-enamel SBS after bleaching. In another study, Prasansuttiporn et al. (30) comparatively investigated the antioxidant effect of $10 \%$ sodium ascorbate solution with $100 \mu \mathrm{M}$ rosmarinic acid on dentin oxidized by $\mathrm{NaOCl}$ irrigation. Rosmarinic acid, which is a phenolic compound isolated from rosemary, was found to be more effective in improving bonding to dentin compared to SA protocol.

Nine different phenolic compounds with antioxidant activity, carnosol, carnosic acid, rosmanol, rosmadial, epirosmanol, isorosmanol, rosmarinidiphenol, rosmariquinone, and rosmarinic acid, were isolated from rosemary extracts (28). Richheimer et al. (29) reported that among all phenolic components of rosemary, carnosic acid had the greatest antioxidant potency, which was three times greater than carnosol and seven times greater than the synthetic antioxidants, BHT and BHA.

Several researchers have shown that the green tea extracts, combined with rosemary (18) or the other plant extracts $(19,20)$ in the accurate concentrations, could create synergistic antioxidant interaction. Contrary to these findings obtained in the food industry research, synergistic antioxidant interaction could not be achieved in the current study, by combining green tea and rosemary antioxidant solutions at a ratio of 1:1.

Synergistic antioxidant interaction depends on combining the appropriate components in the accurate concentrations. The same components that produce a synergistic effect at a certain concentration may produce an antagonistic effect when combined in the other concentrations (16). As a limitation of this study, only a single antioxidant combination protocol was included in the experimental design. Further research is necessary to explore the possible antioxidant synergism between different individual plant extracts and/or isolated bioactive compounds in alternative combinations.

Numerous factors related to the complex nature of the plant extracts e.g. the region where the plant grows, the plant part used to obtain the extract, the extraction method of the plant, the types/ concentrations of the phenolic compounds in the composition of the extract, etc. can have an impact on gathering different results from the antioxidant 
activity studies. Plant extracts do not consist of a pure compound but contain many different antioxidant compounds with different molecular weights. Therefore, when plant extracts are employed for the preparation of the antioxidant solution, the molecular weight of the final solution cannot be determined $(16,31)$. Nevertheless, studies as such, present indirect but useful information on the penetration capacity of the antioxidant compounds through oxidized tooth structures, by reflecting the re-increase in bonding occurred due to the neutralization of the free radicals.

As a low-cost preliminary in vitro research method, plant extract studies contribute and guide the pharmaceutical industry. Natural plant extracts and plant-derived compounds have been investigated for several therapeutic properties that could be beneficial in maintaining oral/dental health, such as wound healing, anti-cariogenic, antibacterial, antiinflammatory, or antioxidant (31). The effects of green tea in decreasing dentin loss caused by erosion (32) alleviating halitosis (33), reducing periodontal inflammation (34), or preventing cavities (35) has been explored in literature. Similarly, the antibacterial effect of rosemary against cariogenic streptococci was also reported (36). Lately, several other therapeutic properties associated with plant extracts and/or isolated bioactive compounds, such as collagenstabilizing, anti-MMP, or dentin modification potential $(37,38)$ have raised great attention in adhesive dentistry.

\section{Conclusion}

Various pharmaceutical drugs/oral care products have been fabricated from the natural active ingredients of the plants or their synthetic derivatives produced under laboratory conditions to date. However, a gold standard antioxidant protocol or a commercially/globally available product with predictable and reproducible therapeutic results could not be generated for clinical use yet. Further studies are needed to explore the therapeutic potential of the different plant extracts/bioactive compounds either alone or combined at the proper proportions.

\section{Acknowledgements}

The authors would like to thank Prof. Dr. Arife Alev Karagözler and Rukiye Yavaşer (Department of Chemistry, Aydın Adnan Menderes University) for preparation of the green tea and rosemary extracts as well as preparation of the experimental antioxidant solutions, Dr. Özkan Eren (Department of Biology, Aydın Adnan Menderes University) for botanical identification of Camellia Sinensis and Rosmarinus Officinalis L. plants, and Kürşat Özkan for assistance with statistical analysis.

\section{Ethics}

Ethics Committee Approval: This study does not require ethics committee approval.

Informed Consent: The patient is not included in this study.

\section{Authorship Contributions}

Concept: S.G., N.A.Y., Design: S.G., N.A.Y., Supervision: S.G., N.A.Y., Fundings: S.G., N.A.Y., Materials: S.G., N.A.Y., Data Collection or Processing: S.G., N.A.Y., Analysis or Interpretation: S.G., N.A.Y., Literature Search: S.G., N.A.Y., Critical Review: S.G., N.A.Y., Writing: S.G., N.A.Y.

Conflict of Interest: No conflict of interest was declared by the authors.

Financial Disclosure: This work was supported by Aydın Adnan Menderes University Scientific Research Project under Grant ADU-BAP DHF-17003.

\section{References}

1. Feiz A, Mosleh H, Nazeri R. Evaluating the effect of antioxidant agents on shear bond strength of tooth-colored restorative materials after bleaching: A systematic review. J Mech Behav Biomed Mater 2017; 71: 156-64.

2. Lai S, Tay F, Cheung G, Mak Y, Carvalho R, Wei S, et al. Reversal of compromised bonding in bleached enamel. J Dent Res 2002; 81: 477-81.

3. Türkün $M$, Kaya $A$. Effect of $10 \%$ sodium ascorbate on the shear bond strength of composite resin to bleached bovine enamel. J Oral Rehabil 2004; 31: 1184-91.

4. Ozelin AA, Guiraldo RD, Carvalho RVD, Lopes MB, Berger SB. Effects of green tea application time on bond strength after enamel bleaching. Braz Dent J 2014; 25: 399-403.

5. Suneetha R, Pavithra S, Thomas J, Nanga GSP, Shiromany A, Shivrayan A. An in vitro comparative study of shear bond strength of composite resin to bleached enamel using synthetic and herbal antioxidants. J Int Oral Health 2014; 6: 77-81.

6. Khamverdi Z, Khadem P, Soltanian A, Azizi M. In vitro evaluation of the effect of herbal antioxidants on shear bond strength of composite resin to bleached enamel. J Dent (Tehran) 2016; 13: 244-51.

7. Bittencourt ME, Trentin MS, Linden MSS, Arsati YBDOL, França FMG, Flório FM, et al. Influence of in situ postbleaching times on 
shear bond strength of resin-based composite restorations. J Am Dent Assoc 2010; 141: 300-6.

8. Guler E, Gonulol N, Ozyilmaz OY, Yucel AC. Effect of sodium ascorbate on the bond strength of silorane and methacrylate composites after vital bleaching. Braz Oral Res 2013; 27: 299-304.

9. Kwon SR, Wertz PW. Review of the mechanism of tooth whitening. J Esthet Restor Dent 2015; 27: 240-57.

10. Perchyonok V, Grobler S. Tooth-bleaching: mechanism, biological aspects and antioxidants. Int J Dent Oral Health 2015; 1: 1-7.

11. Khoroushi M, Feiz A, Khodamoradi R. Fracture resistance of endodontically-treated teeth: effect of combination bleaching and an antioxidant. Oper Dent 2010; 35: 530-7.

12. Park J-Y, Kwon T-Y, Kim Y-K. Effective application duration of sodium ascorbate antioxidant in reducing microleakage of bonded composite restoration in intracoronally-bleached teeth. Restor Dent Endod 2013; 38: 43-7.

13. Nascimento GCR, Guerreiro MYR, Carvalho FF, Força AR, Loretto $\mathrm{SC}$. Does sodium ascorbate improve bond strength after dental bleaching techniques? Rev Odonto Ciênc 2015; 30: 205-10.

14. Freire A, Durski MT, Ingberman M, Nakao LS, Souza EM, Vieira S. Assessing the use of 35 percent sodium ascorbate for removal of residual hydrogen peroxide after in-office tooth bleaching. J Am Dent Assoc 2011; 142: 836-41.

15. LeBlanc JG. Vitamin C-an Update on Current Uses and Functions. Tucumán: Cerela-Conicet Intech Open; 2019.

16. Sonam K, Guleria S. Synergistic antioxidant activity of natural products. Ann Pharmacol Pharm 2017; 2: 1-6.

17. Berger SB, De Souza Carreira RP, Guiraldo RD, Lopes MB, Pavan S, Giannini M, et al. Can green tea be used to reverse compromised bond strength after bleaching? Eur J Oral Sci 2013; 121: 377-81.

18. Mohamed HM. Antioxidant synergy effect of rosemary aqueous extract and green tea flavanol-rich concentrate for superior protection of buffalo meatloaves. Seria Zootehnie 2011; 56: 24252.

19. Jain DP, Pancholi SS, Patel R. Synergistic antioxidant activity of green tea with some herbs. J Adv Pharm Technol Res 2011; 2: 177-83.

20. El-Beltagi HS, Wael E-D, Yousef RS. Synergistic antioxidant scavenging activities of grape seed and green tea extracts against oxidative stress. Not Bot Horti Agrobo 2016; 44: 367-74.

21. Khamverdi Z, Rezaei-Soufi L, Kasraei S, Ronasi N, Rostami S. Effect of Epigallocatechin Gallate on shear bond strength of composite resin to bleached enamel: an in vitro study. Restor Dent Endod 2013; 38: 241-7.

22. Briso ALF, Rahal V, Sundfeld RH, dos Santos P, Alexandre R. Effect of sodium ascorbate on dentin bonding after two bleaching techniques. Oper Dent 2014; 39: 195-203.

23. Boruziniat A, Atoufi A, Chehreli Z, Akbari M, Gifani M. Effect of non-vital bleaching on the durability of resin-dentin bond with an ethanol-based etch-and-rinse adhesive. Biomimetics 2018; 3: $35: 1-8$.
24. Cortez TV, Ziotti IR, Scatolin RS, Corona SAM, Souza-Gabriel AE. Protocols for sodium ascorbate application on intracoronary dentin bleached with high-concentrated agent. J Conserv Dent 2018; 21: 26-31.

25. Bulut $H$, Kaya A, Turkun $M$. Tensile bond strength of brackets after antioxidant treatment on bleached teeth. Eur J Orthod 2005; 27 : 466-71.

26. Chan EW, Soh EY, Tie PP, Law YP. Antioxidant and antibacterial properties of green, black, and herbal teas of Camellia sinensis. Pharmacognosy Res 2011; 3: 266-72.

27. Maruyama T, Tomofuji T, Endo Y, Irie K, Azuma T, Ekuni D, et al. Supplementation of green tea catechins in dentifrices suppresses gingival oxidative stress and periodontal inflammation. Arch Oral Biol 2011; 56: 48-53.

28. Amaral GP, Mizdal CR, Stefanello ST, Mendez ASL, Puntel RL, de Campos MMA, et al. Antibacterial and antioxidant effects of Rosmarinus officinalis L. extract and its fractions. J Tradit Complement Med 2019; 9: 383-92.

29. Richheimer SL, Bernart MW, King GA, Kent MC, Beiley DT. Antioxidant activity of lipid-soluble phenolic diterpenes from rosemary. J Am Oil Chem Soc 1996; 73: 507-14.

30. Prasansuttiporn T, Nakajima $M$, Kunawarote $S$, Foxton RM, Tagami J. Effect of reducing agents on bond strength to $\mathrm{NaOCl}-$ treated dentin. Dent Mater 2011; 27: 229-34.

31. Freires IA, Rosalen PL. How natural product research has contributed to oral care product development? A critical view. Pharm Res 2016; 33: 1311-7.

32. De Moraes MDR, Carneiro JRM, Passos VF, Santiago SL. Effect of green tea as a protective measure against dental erosion in coronary dentine. Braz Oral Res 2016; 30.

33. Narotzki B, Reznick AZ, Aizenbud D, Levy Y. Green tea: a promising natural product in oral health. Arch Oral Biol 2012; 57: 429-35.

34. Mathur A, Gopalakrishnan D, Mehta V, Rizwan S, Shetiya SH, Bagwe S. Efficacy of green tea-based mouthwashes on dental plaque and gingival inflammation: a systematic review and meta-analysis. Indian J Dent Res 2018; 29: 225-32.

35. Ahmed SI, Sudhir KM, Reddy V, Kumar R, Srinivasulu G. Green tea in the prevention of dental caries-A systematic review. Int Arch Biomed Clin Res 2017; 3: 1-6.

36. Tsai $\mathrm{T}-\mathrm{H}$, Chien $\mathrm{Y}-\mathrm{C}$, Lee $\mathrm{C}-\mathrm{W}$, Tsai P-J. In vitro antimicrobial activities against cariogenic streptococci and their antioxidant capacities: A comparative study of green tea versus different herbs. Food Chem 2008; 110: 859-64.

37. Ziotti IR, Palma-Dibb RG, Corona SAM, Evangelista A. Viability of using natural extracts in dental restorative treatment. Eur J Pharm Med Res 2016; 3: 53-61.

38. Santiago SL, Osorio R, Neri JR, Carvalho R, Toledano M. Effect of the flavonoid epigallocatechin-3-gallate on resin-dentin bond strength. J Adhes Dent 2013; 15: 535-40. 